\title{
Professor Iván Antonio Izquierdo (1937-2021)
}

\author{
Professor Iván Antonio Izquierdo (1937-2021) \\ Jaderson Costa DA COSTA'
}

\section{We are what we remember and also \\ what we do not want to remember. Forgetfulness is a good and necessary thing ${ }^{1}$.}

On February $9^{\text {th }}$, 2021, at the age of 83 , Professor Iván Antonio Izquierdo (Figure 1) passed away after a life dedicated to researching the molecular and physiological mechanisms of memory. Prof. Izquierdo was born in Buenos Aires, Argentina, on September 16, 1937. He held an undergraduate degree in Medicine from the University of Buenos Aires (1961), institution in which he also completed his doctorate, and a postdoctoral degree obtained in the Brain Research Institute at the University of California, Los Angeles - UCLA (1962-1964). He held successive teaching positions both abroad - Research Assistant of Anatomy, UCLA (1964); Assistant Professor of Pharmacology, University of Buenos Aires (1965); Professor of Pharmacology, University of Córdoba (1966) - and in Brazil — Professor of Pharmacology, Universidade Federal do Rio Grande do Sul__UFRGS (1973);

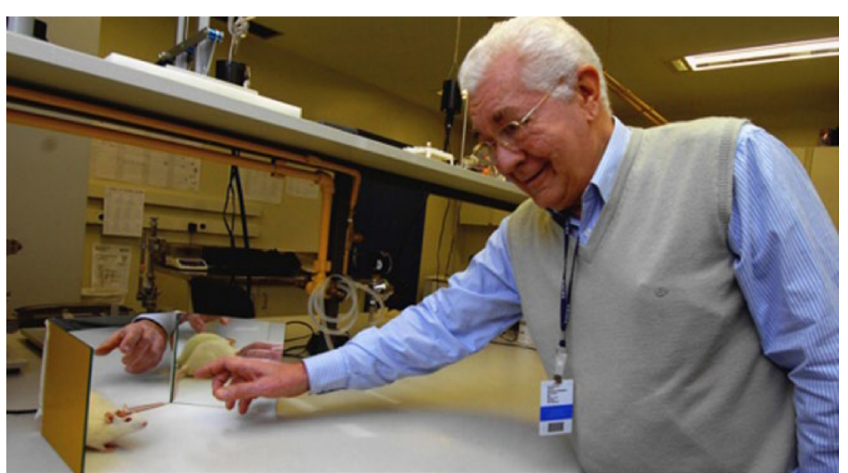

Figure 1. Iván Izquierdo, a life dedicated to studies on memory and teaching, arousing scientific curiosity in students with his thoughts and demonstrations. Memory Center Lab (PUCRS).
Professor of Physiology, School of Medicine, Universidade Federal de São Paulo - UNIFESP (1975); Professor of Biochemistry, UFRGS (1978); Professor of Neurology and Chairman of the Memory Center, Pontifícia Universidade Católica do Rio Grande do Sul. He devoted 61 years to medicine, science and research, and five decades to the study of memory and biochemical processes that regulate its formation, evocation, and extinction and the phenomenon known as Endogenous State Dependence and the functional separation between short and long-term memories (Figure 2) ) $^{2,3,4}$.

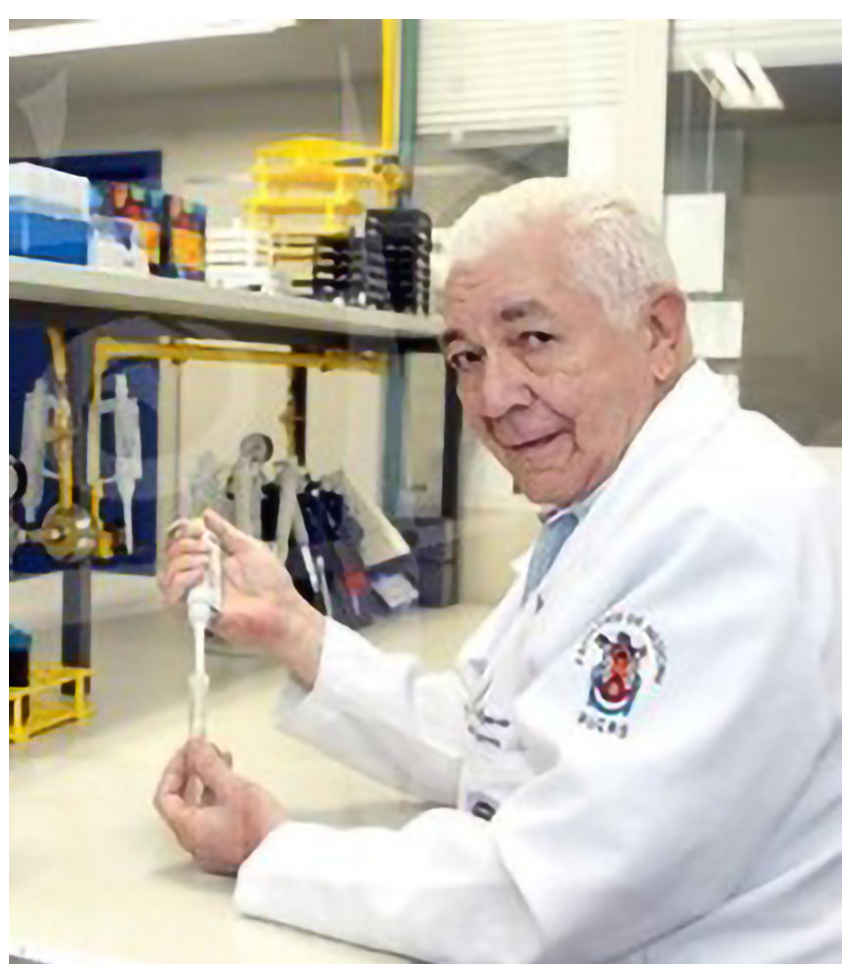

Figure 2. Prof. Izquierdo: from research planning to bench work at the Memory Center (PUCRS). 
Prof. Izquierdo supervised over a hundred masters and doctors who excel in research, teaching, and academic positions. In addition to a talented, innovative, and restless researcher, he was member and director ( for 12 years) of the Brazilian Academy of Sciences, and also a member of the prestigious National Academy of Sciences (USA), among others. His long academic career included the following positions: Professor Emeritus of UFRGS and Honorary Professor of University of Buenos Aires and Córdoba; Doctor Honoris Causa of Universidade Federal do Paraná and Córdoba; and member of the editorial committee of 33 international journals. He was awarded the following distinctions: Grand Cross of the National Order of Scientific Merit, commend of the Order of Rio Branco; Odol Awards (CONICET 1965), TWAS (2005), Conrado Wessel (2008), Raíces (CONICET 2011), Admiral Álvaro Alberto (2011), and UNESCO for Life Sciences (2017). Prof. Izquierdo published over 600 peer-reviewed scientific articles and 24 books (Figure 3 ) not only about his research field, but also decoding science for lay people and about everyday life ${ }^{5,6}$. Izquierdo was a cultured man, who liked good literature. Jorge Luis Borges was his favorite writer and he frequently quoted one of his short stories, Funes, o Memorioso ${ }^{7}$ : "Más recuerdos tengo yo que los que habrá tenido todos los hombres desde que el mundo es mundo."

Prof. Izquierdo propelled the Brazilian research in memory onto the international stage, in addition to training and motivating countless neuroscientists. He leaves an invaluable
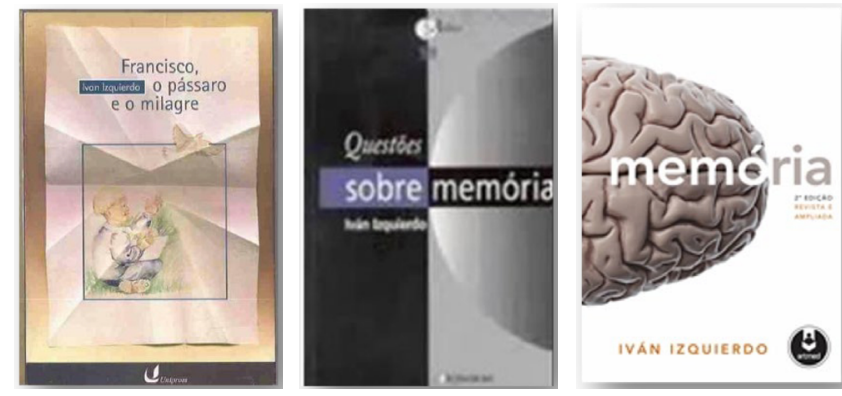

Figure 3. Francisco, the three-year-old grandson at the time, inspired the literary text; questions about memory and memory share the neuroscience of the laboratory with society.

scientific legacy, and a legion of friends and students, and Brazilian neuroscience itself, still under the impact of his loss. We have lost a great man, a talented scientist, and a noble master. Iván leaves his wife Ivone, two children, and four grandchildren.

Interviewer: "And have you imagined that this would be your journey?".

I. Izquierdo - "Yes, but we always make mistakes, right? But I thought it would be something like what my journey has been. I somewhat did what I wanted. What I wanted to be or do, I was and I did. So yes, it is what I have imagined, with some differences, because many things have changed along the way, there were some unexpected changes, like when we left Córdoba, but anyway, I do think so"s.

\section{References}

1. Izquierdo I. A arte de esquecer. cérebro, memória e esquecimento. 2. ed. Rio de Janeiro: Vieira \& Lent; 2010.

2. Izquierdo I, Furini CRG, Myskiw JC. Fear Memory. Physiol Rev. 2016 Apr;96(2):695-750. https://doi.org/10.1152/physrev.00018.2015

3. Izquierdo I. Barros DM, Mello e Souza T, Souza MM, Izquierdo LA, Medina JH. Mechanisms for memory types differ. Nature. 1998 Jun;393(6686):635-6. https://doi.org/10.1038/31371

4. Izquierdo I, Bevilaqua LRM, Rossato JI, Bonini JS, Medina $\mathrm{JH}$, Cammarota M. Different molecular cascades in different sites of the brain control memory consolidation. Trends Neurosci. 2006 Sep;29(9):496-505. https://doi.org/10.1016/j. tins.2006.07.005

5. Izquierdo I. Memória. Porto Alegre: ArtMed; 2002.

6. Izquierdo I. Francisco, o pássaro e o milagre. Porto Alegre: Editora Uniprom; 2000.

7. Borges JL. Ficciones. Buenos Aires: Emecé; 1944.

8. Interview with journalist Flavia Polo from InsCer; 2019. 